\title{
Anesthesia Equipment
}

\section{In vitro diffusion of lidocaine across endo- tracheal tube cuffs}

\author{
Chun-Jen Huang $M D$, * \\ Ming-Chuan Tsai Ms, $\dagger$ \\ Chien-Tsu Chen PhD, $\ddagger$ \\ Ching-Rong Cheng $\mathrm{MD}$, * \\ Kuo-Hwa Wu MD, * \\ Tze-Taur Wei MD*
}

Purpose: Lidocaine diffuses across endotracheal tube cuffs, which may serve as a reservoir for local anesthetic to assist in the prevention of ETT-induced cough while emerging from general anesthesia. However, the rate of diffusion is slow. Two techniques, alkalization and warming, may increase the proportion of uncharged drug available for diffusion. The purpose of this study is to determine the effectiveness of warming alkalization or warming with alkalization on diffusion.

Methods: Four preparations of lidocaine $4 \%$ were studied. Group $(\mathrm{Gr}) \mathrm{L}$-lidocaine $\left(24^{\circ} \mathrm{C}\right), \mathrm{Gr} \mathrm{WL}$ - warmed lidocaine $\left(38^{\circ} \mathrm{C}\right)$, Gr AL - alkalized lidocaine $\left(24^{\circ} \mathrm{C}\right)$, Gr WAL - warmed, alkalized lidocaine $\left(38^{\circ} \mathrm{C}\right)$. Twenty-four Mallinckrodt 8.0 ID (Mallinckrodt Critical Care Division of Mallinckrodt, Inc., Glens Falls, New York) endotracheal tube cuffs were filled with $6 \mathrm{ml}$ of one of the four preparations. They were then placed in a $20 \mathrm{ml}$ water bath at $38^{\circ} \mathrm{C}$ and samples were drawn from the water bath at intervals for up to $360 \mathrm{~min}$. The lidocaine concentration in each sample was determined by gas chromatography.

Results: The highest lidocaine concentration was reached in Gr WAL $\left(410.98 \pm 8.53 \mu \mathrm{g} \cdot \mathrm{ml}^{-1}\right)$ after 300 min and then decreased to $376.18 \pm 4.59 \mu \mathrm{g} \cdot \mathrm{ml}^{-1}$ after $360 \mathrm{~min}$. In $\mathrm{Gr}$ AL the highest concentration $(235.05 \pm 2.99$ $\mu \mathrm{g} \cdot \mathrm{ml}^{-1}$ ) was reached after $360 \mathrm{~min}$. Lidocaine concentrations in $\mathrm{Gr} L$ and $W \mathrm{~L}$ after $360 \mathrm{~min}$ were $3.19 \pm 1.16$ $\mu \mathrm{g} \cdot \mathrm{ml}^{-1}$ and $4.32 \pm 2.02 \mu \mathrm{g} \cdot \mathrm{ml}^{-1}$ respectively.

Conclusion: Alkalization with or without warming, but not warming alone, promotes lidocaine diffusion from endotracheal tube cuff.

Objectif : La lidocaine diffuse, lentement toutefois, au travers des ballonnets des tubes endotrachéaux. Les ballonnets peuvent servir de réservoir à l'anesthésique local et participer à la prévention de la toux induite par le TET pendant la récupération de l'anesthésie générale. Lalcalinisation et le réchauffement peuvent accroître la proportion de médicament susceptible de diffuser. L'objectif de la présente étude est de déterminer l'efficacité du réchauffement, seul ou avec alcalinisation, sur la diffusion.

Méthode : On a étudié quatre préparations de lidocaine. Le groupe $(\mathrm{Gr}) \mathrm{L}$-lidocaïne $\left(24^{\circ} \mathrm{C}\right), \mathrm{Gr} \mathrm{LR}$ - lidocaïne réchauffée $\left(38^{\circ} \mathrm{C}\right)$, Gr LA - lidocaïne alcalinisée $\left(24^{\circ} \mathrm{C}\right)$, Gr LRA - lidocaïne réchauffée, alcalinisée $\left(38^{\circ} \mathrm{C}\right)$. Vingtquatre tubes endotrachéaux à ballonnets Mallinckrodt de DI 8,0 (Mallinckrodt Critical Care Division of Mallinckrodt, Inc., Glens Falls. New York) ont été remplis de $6 \mathrm{ml}$ de l'une des préparations. Placés ensuite dans un bain d'eau de $20 \mathrm{ml}$ à $38^{\circ} \mathrm{C}$, on en a ensuite retiré des échantillons à des intervalles pouvant aller jusqu'à 360 min. La concentration de lidocaïne a été déterminée par chromatographie en phase gazeuse.

Résultats : La plus forte concentration de lidocaïne a été atteinte dans le Gr LRA, 410,98 $\pm 8,53 \mu \mathrm{g} \cdot \mathrm{ml}^{-1}$, après $300 \mathrm{~min}$, puis elle a baissé à 376,18 \pm 4,59 $\mu \mathrm{g} \cdot \mathrm{ml}^{-1}$ après $360 \mathrm{~min}$. Dans le Gr LA, la concentration maximale était de $235,05 \pm 2,99 \mu \mathrm{g} \cdot \mathrm{ml}^{-1}$ après $360 \mathrm{~min}$. Dans les $\mathrm{Gr} L$ et $L R$, la lidocaïne était, après $360 \mathrm{~min}$ de $3,19 \pm$ $1,16 \mu \mathrm{g} \cdot \mathrm{ml}^{-1}$ et de $4,32 \pm 2,02 \mu \mathrm{g} \cdot \mathrm{ml}^{-1}$ respectivement.

Conclusion : L'alcalinisation avec ou sans réchauffement, mais non le réchauffement employé seul, favorise la diffusion de la lidocaïne au travers du ballonnet du tube endotrachéal.

From the Department of Anesthesiology, Mackay Memorial Hospital, " School of Medical Technology† and Graduate Institute of Medical Sciences and Biochemistry, $\ddagger$ Taipei Medical College.

Address correspondence to: Chun-Jen Huang md, Department of Anesthesiology, Mackay Memorial Hospital, 92, Sec 2, Chung San N. Rd., Taipci 10449, Taiwan. Phone: 886-2-25433535 Ext. 3009; Fax: 886-2-25433642; E-mail: sean@ms2.mmh.org.tw Supported by a grant of the Mackay Memorial Hospital, Taipei, Taiwan, R.O.C. (MME-8503).

Accepted for publication October 16, 1998 


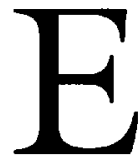

MERGENCE from general anesthesia is frequently complicated by endotracheal tube (ETT) induced coughing. This can result in potentially dangerous patient movement, hypertension, tachycardia or other arrhythmia, myocardial ischemia, surgical bleeding, bronchospasm, and increases in intracranial and intraocular pressure. ${ }^{1,2} \mathrm{~A}$ reliable technique for improving ETT tolerance while facilitating rapid and full emergence from general anesthesia would be desirable in many situations. "Deep" extubation (removal of the ETT while the patient is still in a deep plane of general anesthesia), administration of intravenous (iv) opioids or iv lidocaine, and local lidocaine spray prior to emergence have been used to diminish coughing. ${ }^{1,3-9}$

Although some authors consider "deep" extubation to be an effective technique to prevent coughing during emergence from general anesthesia, ${ }^{3,5}$ loss of airway protection and aspiration is a major drawback. Intravenous lidocaine in doses of $1.0-2.0 \mathrm{mg} \cdot \mathrm{kg}^{-1}$, producing a plasma lidocaine level $\left(3 \mu \mathrm{g} \cdot \mathrm{ml}^{-1}\right)$ can transiently suppress coughing and other airway reflexes. ${ }^{4-9}$ However, the duration of $i v$ lidocaine is short (5-20 min) ${ }^{8}$ This narrow antitussive window makes the optimal time of administration during emergence very difficult. Intravenous lidocaine, as well as iv opioids, also produces sedation and results in delay in emergence from anesthesia. ${ }^{3,9}$ To achieve the simultaneous goals of cough suppression and full awakening, better techniques are needed.

Rapidly adapting stretch receptors (RAR) in the tracheal mucosa are believed to be irritant receptors involved in the cough reflex. ${ }^{10,11}$ The minimal blocking concentration $\left(\mathrm{C}_{\mathrm{m}}\right)$ of lidocaine for RAR within $15 \mathrm{~min}$ is about $155 \mu \mathrm{g} \cdot \mathrm{ml}^{-1} .^{11}$ Time appears to be an important factor in developing neural blockade. The $\mathrm{C}_{\mathrm{m}}$ for the frog sciatic nerve within $10 \mathrm{~min}$ and within $40 \mathrm{~min}$ were $500-700 \mu \mathrm{g} \cdot \mathrm{ml}^{-1}$ and $42 \mu \mathrm{g} \cdot \mathrm{ml}^{-1}$ respectively. ${ }^{12}$ Topically applied local anesthetics also block the receptors. ${ }^{10,11}$ Local lidocaine spray prior to extubation effectively suppresses ETT- induced coughing. ${ }^{3,5,11}$ However, specially designed instruments for the delivery of lidocaine are usually required. ${ }^{3,5}$ Furthermore, local administration of lidocaine may exert a local irritant effect long before cough suppression ensues.

Lidocaine diffuses across ETT cuffs, which may enable the cuff to serve as a reservoir for local anesthetic. ${ }^{13}$ However, the rate of lidocaine diffusion across ETT cuffs is slow. Endotracheal tube cuffs are commonly made from polyvinyl chloride (PVC), a largely hydrophobic chemical substance. Therefore, the mechanism of lidocaine diffusion across an ETT cuff may be similar to that found in the epidural space. ${ }^{14}$ Local anesthetics applied to a nerve membrane exist in two forms: non-ionized free-base and ionized cation. An increase in the non-ionized fraction of the local anesthetic results in improved nerve penetration and more rapid onset of nerve blockade. ${ }^{15-17}$ It is reasonable to speculate that an increase in the nonionized fraction may prompt local anesthetics to diffuse more rapidly across an ETT cuff. Increasing the $\mathrm{pH}$ of the solution can predictably increase the percentage of the non-ionized form. ${ }^{15,18-20}$ The proportion of the drug that is uncharged also depends on the $\mathrm{pK}_{\mathrm{a}}$ - its dissociation constant, which is temperaturedependent. ${ }^{15-17,21}$ As a local anesthetic is warmed, the $\mathrm{pK}_{\mathrm{a}}$ decreases and the proportion of uncharged drug available for action increases. ${ }^{15-17,21}$

Therefore, alkalization and warming are two techniques that are frequently used to increase the proportion of uncharged drug. Addition of bicarbonate resulted in a 63-fold increase in the diffusion of ETT lidocaine. ${ }^{22}$ The purpose of this study is to determine the effect of warming, alkalization, or warming with alkalization on lidocaine diffusion across the ETT cuff.

\section{Materials and methods}

Twenty-four Mallinckrodt 8.0 ID (Mallinckrodt Critical Care Division of Mallinckrodt, Inc., Glens Falls, New York) ETTs were prepared and divided into four groups. Four preparations of lidocaine $4 \%$ solution were studied. Group (Gr) L: $6 \mathrm{ml}$ lidocaine $4 \%$ solution @ $24^{\circ} \mathrm{C}$ (control group); Gr WL $6 \mathrm{ml}$ warmed $\left(38^{\circ} \mathrm{C}\right)$ lidocaine $4 \%$ solution; Gr AL $6 \mathrm{ml}$ alkalized lidocaine $4 \%$ solution $\left(5 \mathrm{ml} 24^{\circ} \mathrm{C}\right.$ lidocaine $4 \%+1 \mathrm{ml}$ sodium bicarbonate $7 \%$; Gr WAL $6 \mathrm{H}$ warmed and alkalized lidocaine $4 \%$ solution $(5 \mathrm{ml}$ $38^{\circ} \mathrm{C}$ lidocaine $4 \%+1 \mathrm{ml}$ sodium bicarbonate $7 \%$ ). The $\mathrm{pH}$ of all solutions was measured by $\mathrm{pH}$ meter (AB $15 \mathrm{plVmV} /{ }^{\circ} \mathrm{C}$, Fisher Scientific Co., Pittsburgh, PA. USA).

Each ETT cuff was filled with $6 \mathrm{ml}$ of one of the four preparations of lidocaine. Rubber bands were applied to maintain the cuff pressure, as measured by a manometer, at $20 \mathrm{~cm} \mathrm{H} \mathrm{H}_{2} 0$. Each ETT was then placed in a magnetically stirred bath of $20 \mathrm{ml}$ distilled water at $38^{\circ} \mathrm{C}$. Samples $(100 \mu \mathrm{l})$ of the bath contents were drawn after $5,10,15,30,45,60,90,120,180$, 240,300 and $360 \mathrm{~min} \mathrm{~A} 0.5 \mu \mathrm{g}$ aliquot of bupivacaine was then added to each sample to provide an internal concentration standard.

To determine the lidocaine concentration, $5 \mu \mathrm{l}$ of each sample were injected on to a column (HP-5MS) in a Hewlett-Packard (HP) model 5890A gas chromatograph (GC) equipped with a flame ionization detector (FID). Details of the operation are described 
TABLE Lidocaine concentration $\left(\mu \mathrm{g} \cdot \mathrm{ml}^{-1}\right)$ in bath

\begin{tabular}{llllllll}
\hline \multicolumn{7}{c}{ Time (min) } \\
\hline Group & $n$ & 5 & 10 & 15 & 30 & 45 & 60 \\
L & 6 & $0.00 \pm 0.00$ & $0.00 \pm 0.00$ & $0.13 \pm 0.02$ & $0.15 \pm 0.02$ & $0.19 \pm 0.15$ & $0.23 \pm 0.11$ \\
WL & 6 & $0.00 \pm 0.00$ & $0.19 \pm 0.12^{*}$ & $0.31 \pm 0.13$ & $0.46 \pm 0.24$ & $0.51 \pm 0.45$ & $0.73 \pm 0.40$ \\
AL & 6 & $0.16 \pm 0.02^{\star}$ & $0.31 \pm 0.03^{*}$ & $0.49 \pm 0.05^{*}$ & $0.84 \pm 0.05^{\star}$ & $1.23 \pm 0.47 \dagger$ & $3.44 \dagger 0.60 \dagger$ \\
WAL & 6 & $0.25 \pm 0.01^{*}$ & $0.43 \pm 0.05^{*}$ & $0.63 \pm 0.07 \dagger$ & $1.26 \pm 0.10 \dagger$ & $1.91 \pm 0.12 \ddagger$ & $25.83 \pm 1.78 \ddagger$ \\
& & & & & & 300 & 360 \\
L & 6 & 90 & 120 & 180 & 240 & $2.86 \pm 1.48$ & $3.19 \pm 1.16$ \\
WL & 6 & $0.99 \pm 0.24$ & $1.21 \pm 0.57$ & $1.84 \pm 1.10$ & $2.17 \pm 1.10$ & $3.85 \pm 1.09$ & $4.32 \pm 2.02$ \\
AL & 6 & $38.71 \pm 1.83 \dagger$ & $116.77 \pm 7.24 \dagger$ & $150.32 \pm 13.16 \dagger$ & $166.44 \pm 21.28 \dagger$ & $219.95 \pm 11.57 \dagger$ & $235.05 \pm 2.99 \dagger$ \\
WAL & 6 & $83.14 \pm 1.07 \ddagger$ & $133.57 \pm 2.15 \ddagger$ & $224.17 \pm 11.42 \ddagger$ & $309.55 \pm 18.97 \ddagger$ & $410.98 \pm 8.53 \ddagger$ & $376.18 \pm 4.59 \ddagger$ \\
\hline
\end{tabular}

Valucs are mean $\pm \mathrm{SD}$

* $P<0.05, \dagger P<0.01, \ddagger P<0.001$ compared with the control group.

in the appendix. The Figure illustrates the gas chromatographic separation of lidocaine (peak 6.18-min) from the internal standard (peak 7.64-min). Quantification of the concentrations of lidocaine and the internal standard were automatically calculated within the areas of the peaks.

One-way ANOVA was used for data analysis. Tukey's honesty significant difference test was the post-hoc test applied after ANOVA. Data were presented as the mean \pm standard deviation (SD). Statistical significance was defined as $P<0.05$. The software package for analysis was SPSS for Windows.

\section{Results}

The $\mathrm{pH}$ values of $\mathrm{Gr} \mathrm{AL}$ and WAL were $7.34 \pm 0.11$. The $\mathrm{pH}$ values of $\mathrm{Gr} \mathrm{L}$ and $\mathrm{WL}$ were $6.42 \pm 0.15$.

Each group demonstrated an increase in the concentration of lidocaine in the bath with time (Table). Lidocaine, in Gr AL and WAL, could be detected after five minutes. The lidocaine concentration in Gr WAL was the highest among the four groups throughout the study followed by Gr AL. There were no differences between $\mathrm{Gr} L$ and WL except after ten minutes when, in $\mathrm{Gr}$ WL, lidocaine concentration was first detected $\left(0.19 \pm 0.12 \mu \mathrm{g} \cdot \mathrm{ml}^{-1}\right)$ while in $\mathrm{Gr} \mathrm{L}$ it was undetectable.

In Gr WAL the highest concentration $(410.98 \pm$ $8.53 \mu \mathrm{g} \cdot \mathrm{ml}^{-1}$ ) was reached after $300 \mathrm{~min}$ and then decreased to $376.18 \pm 4.59 \mu \mathrm{g} \cdot \mathrm{ml}^{-1}$ after $360 \mathrm{~min}$. In Gr AL the highest concentration $(235.05 \pm 2.99$ $\mu \mathrm{g} \cdot \mathrm{ml}^{-1}$ ) was reached after $360 \mathrm{~min}$. Lidocaine concentrations of $\mathrm{Gr} \mathrm{L}$ and $\mathrm{WL}$ after $360 \mathrm{~min}$ were 3.19 $\pm 1.16 \mu \mathrm{g} \cdot \mathrm{ml}^{-1}$ and $4.32 \pm 2.02 \mu \mathrm{g} \cdot \mathrm{ml}^{-1}$ respectively. Each cuff was rigorously tested for leakage at the end of the study and all remained intact.

\section{Discussion}

In this study, the $\mathrm{pH}$ of lidocaine solution was raised from $\mathrm{pH} 6.42 \pm 0.15$ to a physiological ${ }^{21} \mathrm{pH}$ of $7.34 \pm 0.11$ by adding $1 \mathrm{ml}$ sodium bicarbonate $7 \%$ to $5 \mathrm{ml}$ lidocaine $4 \%$ solution. In case of cuff rupture, the amount of lidocaine was limited to clinically acceptable doses and toxic loading doses of lidocaine were avoided. ${ }^{22}$

The $20 \mathrm{ml}$ distilled water used in this study might more closely simulate the tracheal environment than the $200 \mathrm{ml}$ normal saline bath used by Sconzo et al., ${ }^{13}$ suggesting that our results may better parallel the physiological environment. They also found a higher lidocaine concentration after $360 \mathrm{~min}$ in ETT cuffs filled with plain lidocaine $4 \%$, than we did (14.78 \pm $1.28 \mu \mathrm{g} \cdot \mathrm{ml}^{-1}$ ps $\left.3.19 \pm 1.16 \mu \mathrm{g} \cdot \mathrm{ml}^{-1}\right)$. One explanation is that Sconzo et al. ${ }^{13}$ concentrated their samples before the samples were injected into the port of GCFID, while we did not.

Warming alone did not exert any effect on lidocaine diffusion. As we did not observe any differences between $\mathrm{Gr} L$ and WL except after ten minutes when, in Gr WL, lidocaine concentration was first detected $\left(0.19 \pm 0.12 \mu \mathrm{g} \cdot \mathrm{ml}^{-1}\right)$ while in $\mathrm{Gr} \mathrm{L}$ it was still undetectable. The initial temperature differences probably no longer existed after ten minutes, since both sets of ETTs were placed in a water bath at $38^{\circ} \mathrm{C}$. However, alkalization did effect lidocaine diffusion. Matias indicated that alkalization of lidocaine in ETT cuffs caused a 63 -fold increase in diffusion. ${ }^{22}$ We observed a similar result. Compared with the control group, there was a 73 -fold increase in lidocaine diffusion after 360 $\mathrm{min}$ in $\mathrm{Gr} \mathrm{AL}\left(235.05 \pm 2.99\right.$ ps $\left.3.19 \pm 1.16 \mu \mathrm{g} \cdot \mathrm{ml}^{-1}\right)$. Furthermore, alkalization with warming also effected lidocaine diffusion. In Gr WAL, we observed a 118 fold increase after $360 \min (376.18 \pm 4.59$ vs $3.19 \pm$ 


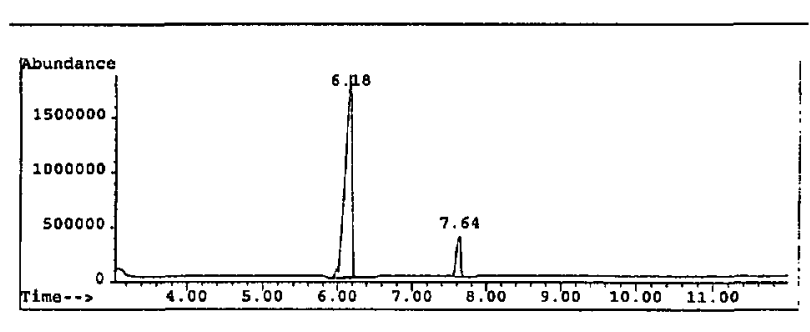

FIGURE The gas chromatographic separation of lidocaine (peak 6.18-min) from the internal standard (peak 7.64-min). Quantitation of the concentrations of lidocaine and the internal standard were automatically calculated within the areas of the peaks.

\section{$\left.1.16 \mu \mathrm{g} \cdot \mathrm{ml}^{-1}\right)$.}

It is more difficult to explain why the concentration of lidocaine peaked after 300 than $360 \mathrm{~min}$ in $\mathrm{Gr}$ WAL. Generally, lidocaine diffusion is time-dependent. In this in vitro study, metabolism would not be expected to play a role, and we found no peaks other than single lidocaine and single bupivacaine peaks. Further studies are needed to elucidate this question.

The $\mathrm{C}_{\mathrm{m}}$ of the RAR within $15 \mathrm{~min}$ was about 155 $\mu \mathrm{g} \cdot \mathrm{ml}^{-1} \cdot{ }^{11}{ }^{\mathrm{m}}$ In $\mathrm{Gr} \mathrm{AL}$, the lidocaine concentration reached $150 \mu \mathrm{g} \cdot \mathrm{ml}^{-1}$ at after $180 \mathrm{~min}$. Lidocaine concentration in Gr WAL reached $133.57 \pm 2.15 \mu \mathrm{\mu g} \cdot \mathrm{ml}^{-1}$ at after $120 \mathrm{~min}$. These suggest that, through manipulation of alkalization with or without warming, lidocaine in ETT cuffs may exert its RAR blocking effect within two to three hours after its application. Furthermore, an ETT cuff in the trachea presses on the mucosa, thus decreasing the space for intervening fluid and presumably lessening the chance of dilution. Therefore, we can expect a much higher local concentration of lidocaine in vivo than in vitro. Time is also important in developing neural blockade with local anesthetics. ${ }^{12}$ The longer the RARs are exposed to local anesthetics, the lower the concentration needed to produce blockade. If we also take the duration that the RAR is exposed to lidocaine into consideration, effective blockade of the RAR might occur earlier than two hours after lidocaine application.

Based on our results, we propose using either $1 \mathrm{ml}$ sodium bicarbonate $(7 \%)$ and $5 \mathrm{ml}$ lidocaine $4 \%$ at $38^{\circ} \mathrm{C}$ or $1 \mathrm{ml}$ sodium bicarbonate $7 \%$ and $5 \mathrm{ml}$ lidocaine $4 \%$ at $24^{\circ} \mathrm{C}$ to inflate the ETT cuff in order to decrease or prevent ETT-induced coughing during emergence from general anesthesia for longer operative procedures. These regimens may not be beneficial for shorter procedures because of the slow onset of action. However, these regimens might be of great benefit for those patients who need prolonged intubation, e.g. ICU patients.

\section{Conclusion}

Alkalization with or without warming, but not warming alone, promotes lidocaine diffusion from endotracheal tube cuffs.

\section{Appendix}

The GC-FID, Hewlett-Packard (HP) model 5890A gas chromatograph equipped with a flame ionization detector (FID), operated in a split injection mode with a split ratio of 50:1. The column used was a HP$5 \mathrm{MS}(30 \mathrm{~m} \times 0.25 \mathrm{~mm} \times 0.25 u \mathrm{~m})$. Helium was used as carrier gas at a flow rate of $1 \mathrm{ml} \cdot \mathrm{min}^{-1}$. The column oven temperature was programmed as follows: $150^{\circ} \mathrm{C}$ for one minute, then raised at a rate of $30^{\circ} \mathrm{C} \cdot \mathrm{min}^{-1}$ to $300^{\circ} \mathrm{C}$ where the temperature was maintained for four minutes. Detector and injector temperatures were held at $320^{\circ} \mathrm{C}$ and $230^{\circ} \mathrm{C}$ respectively. Lidocaine (peak 6.18-min) would be separated from the internal standard (peak 7.64- min) by GC-FID. Quantification of the concentrations of lidocaine and the internal standard were automatically calculated within the areas of the peaks. Duplicate serial dilutions of stock standards were used for the standard curve. The correlation coefficient of the standard curve was 0.992 . The practical lower limit of sensitivity for this procedure was $0.06 \mu \mathrm{g} \cdot \mathrm{ml}^{-1}$. The coefficient of variation of this assay was $5.78 \%$.

\section{Acknowledgment}

The authors gratefully acknowledge Dr. Cosmo A. Difazio for his opinions of the study design. We also thank Mr. Haw-Mng Huang for technical assistance.

\section{References}

1 Bidwai AV, Bidwai VA, Rogers CR, Stanley TH. Bloodpressure and pulse-rate responses to endotracheal extubation with and without prior injection of lidocaine. Anesthesiology 1979; 51: 171-3.

2 Leech P, Barker J, Fitch W. Changes in intracranial pressure and systemic arterial pressure during the termination of anaesthesia. Br J Anaesth 1974; 46: 315-6.

3 Gonzalez RM, Bjerke RJ, Drobycki T, et al. Prevention of endotracheal tube-induced coughing during emergence from general anesthesia. Anesth Analg 1994; 79 : 792-5.

4 Steinhaus JE, Gaskin L. A study of intravenous lidocaine as a suppressant of cough reflex. Anesthesiology 1963; 24: 285-90.

5 Poulton TJ, James FM III. Cough suppression by lidocaine. Anesthesiology 1979; 50: 470-2. 
6 Gefke $K$, Andersen LW, Friesel E. Lidocaine given intravenously as a suppressant of cough and laryngospasm in connection with extubation after tonsillectomy. Acta Anaesthesiol Scand 1983; 27: 111-2.

7 Christensen V, Ladegaard-Pedersen HJ, SkovstedP. Intravenous lidocaine as a suppressant of persistent cough caused by bronchoscopy. Acta Anaesthesiol Scand 1978; 67(Suppl): 84-6.

8 Yukioka $H$, Yoshimoto $N$, Nishimura $K$, Fujimori $M$. Intravenous lidocaine as a suppressant of coughing during tracheal intubation. Anesth Analg 1985; 64: 1189-92.

9 Nishino T, Hiraga K, Sugimori K. Effects of i.v. lignocaine on airway reflexes elicited by irritation of the tracheal mucosa in humans anaesthetized with enflurane. Br J Anaesth 1990; 64: 682-7.

10 Bartlett D Jr, Jeffrey P, Sant'Ambrogio G, Wise JCM. Location of stretch receptors in the tracheal and bronchi of the dog. J Physiol (Lond) 1976; 258: 409-20.

11 Camporesi EM, Mortola JP, Sant'Ambrogio F, Sant'Ambrogio $G$. Topical anesthesia of tracheal receptors. J Appl Physiol 1979; 47: 1123-6.

12 Strobel GE, Bianchi CP. The effects of $\mathrm{pH}$ gradients on the uptake and distribution of $\mathrm{C}^{\mathbf{1 4}}$-procaine and lido caine in intact and desheathed sciatic nerve trunks. J Pharmacol Exp Ther 1970; 172: 18-32.

13 Sconzo JM, Moscicki JC, Difazio CA. In vitro diffusion of lidocaine across endotracheal tube cuffl. Reg Anesth 1990; 15: 37-40.

14 dejong $R H . \mathrm{C}_{\mathrm{m}}$ - The minimum blocking concentration. In: deJong RH (Ed.). Local Anesthetics. Springfield, Illinois: Charles C Thomas, 1977: 51-62.

15 Butterworth JF, Strichartz GR. Molecular mechanisms of local anesthesia: a review. Anesthesiology 1990; 72: 711-34.

16 Sanchez V, Arthur GR, Strichartz GR. Fundamental properties of local anesthetics. I. The dependence of lidocaine's ionization and octanol: buffer partitioning on solvent and temperature. Anesth Analg 1987; 66: 159-65.

17 Strichartz GR, Sanchez V, Artbur GR, Chafetz $R$, Martin D. Fundamental properties of local anesthetics. II. Measured octanol: buffer partition coefficients and $\mathrm{pK}_{\mathrm{a}}$ values of clinically used drugs. Anesth Analg 1990; 71: 158-70.

18 Difazio CA, Carron $H$, Grosslight KR, Moscicki JC, Bolding $W R$, Johns $\mathrm{RA}$. Comparison of $\mathrm{pH}$-adjusted lidocaine solutions for epidural anesthesia. Anesth Analg 1986; 65: 760-4.

19 Fernando $R$, Jones HM. Comparison of plain and alkalinized local anaesthetic mixtures of lignocaine and bupivacaine for elective extradural Caesarean section Br J Anaesth 1991; 67: 699-703.
20 Galindo A. pH-Adjusted local anesthetics: clinical experience. Reg Anaesth 1983; 8: 35-6.

21 Clark V, McGardy E, Sugden C, Dickson J, McLeod G. Speed of onset of sensory block for elective extradural Caesarean section: choice of agent and temperature of injectate. Br J Anaesth 1994;72: 221-3.

22 Matias $E$. Effect of $\mathrm{NaHCO}_{3}$ On the diffusion of lignocaine through the wall of endotracheal tube's cuff. Br J Anaesth 1995; 74: A.238. 